\title{
Learning Fraction With Indonesia Realistic Mathematics Education (PMRI)
}

\author{
a Melva Zainil \\ State University of Padang, Padang \\ Corresponding e-mail: melva_zainil@yahoo.com
}

\begin{abstract}
This paper is aimed to describe the activity of designing learning activities, implementation, and the effect of the activity to student learning outcomes. The plan activities are aimed to support $4^{\text {th }}$ grade of SDN 20 Indarung Padang students on understanding in fractional addition by using Realistic Mathematics Education (RME) Approach. The research itself utilize classroom action research design with qualitative and quantitative research approaches. There two cycles that would be explained in the paper. Each cycle consists of planning, execution, observation, and reflection. The results showed an increase in every aspect that are observed. The effectivity of lesson plan increases from $89.29 \%$ in cycle I to $96.43 \%$ in cycles II. Teacher's activity go up from $75 \%$ in cycle I to $95 \%$ on the cycle II. It is also affected students'activities from $77.5 \%$ to $95 \%$. The average of Students cognitive, affective and psychomotor learning outcomes improves respectively from 74.22 to $83.75,66.54$ to 80.47 , and 66.54 to 80.47 . It can be concluded that the RME approach improve students' understanding of addition of fractions, students' affective and psychomotor learning outcomes of $4^{\text {th }}$ grade of SDN 20 Indarung Padang.
\end{abstract}

Keywords: PMRI, fractions and action research

\section{INTRODUCTION}

Mathematics is the source of all disciplines and key feature of science. Mathematics also uses to serve the science which means it plays important roles to support other disciplines to develop and to be used in solving human problems. Permendiknas No.22 on Depdiknas (2006: 417) stated several objectives of mathematics learning as follows:

(1) Understanding mathematical concepts, explaining the interconnectedness of concepts and applying concepts or logarithms, flexibly, accurately, efficiently, and appropriately, in problem solving; (2) Using reasoning on patterns and traits, performing mathematical manipulations in generalizing, compiling evidence, or explaining mathematical ideas and statements; (3) Solve problems that include the ability to understand problems, design mathematical models, solve models and interpret the obtained solutions; (4) Communicating ideas with symbols, tables, and diagrams, or other media to clarify circumstances or problems; (5) Having an appreciation of the usefulness of mathematics in life, which has a curiosity, attention, and interest in learning mathematics, as well as a tenacious attitude and confidence in problem solving.

Fraction is one of subject that is taught in primary school. One of difficulties that is faced by students is understanding the addition of fraction with different denominations. The curriculum requires students to solve daily life problems related to the addition of fraction.

Moreover, studying the addition of fraction for elementary school students should be started with real context. BNSP (2006:416) curriculum demands that 
"learning mathematics should begin with the introduction of problems appropriate to the situation". In addition, $4^{\text {th }}$ grades students of aged 9-10 require media that can be manipulated and used by students in understanding the concept of addition of different denomination fractions. They can not fully understand abstract abstract concepts. therefore, the concrete object or real activities are needed to build a primary understanding in the sum of fraction. as Peaget's (in Zainul and Mulyana, 2007: 418) which states that "Students of aged 7-11 years are at concrete operational stage". Students at this stage have not been able to comprehend abstract learning so that the learning material must be concretized.

Based on observations in $4^{\text {th }}$ grade SDN 20 Indarung Padang students class, teacher tend to use conventional approach where teacher explain and write the key point of concept on blackboard. Students are not encouraged to understand the concept, but more to memorize the concept and the example of the use of concept in solving mathematical problems. Students are forced to solve several questions related with the explained concepts. Teachers focus more on students to remember ways teachers are taught rather than stimulate students to construct knowledge and develop students' creative ideas in solving problems. Teachers have not modeled math learning. This resulted in most students having difficulties in understanding the concepts of mathematics because what is learned is abstract.

In addition, teachers are less likely to give students the opportunity to speak and express their opinions. This condition lead to inactive classroom environment. students are not able to express their idea, implement idea and evaluate what they do. Even, some students become passive and do not have the courage to express their idea in front of others. Teachers also do not provide opportunities to students in constructing their own knowledge, investigating facts, and making conclusion about their finding.

These conditions have lead to low students learning outcomes in addition of fraction with different denomination. a real action need to be done in facilitating and supporting students to actively involve in constructing their own knowledge.

One way to solve the problem is using Realistic Mathematics Education (RME) approach. This approach begins with real context or real-life problems, involves students actively in constructing mathematics concepts, and facilitates students to express, argue, implement and evaluate their idea. Fauzan (2002: 35) states that, "the process of developing mathematical concepts and ideas starts from the real life, and connects the obtained solutions back to real life". it can be concluded that learning should be begun with reality based problem, analyze and solve the problem, build or construct mathematics concepts, and use the concept to solve other reality based problem. These processes lead to a conceptual mathematical understanding.

Based on the encountered problems and the possible solution that are described above, this research will focus on finding a way to improve students learning outcomes in understanding the concept of addition of fraction with different denomination by using realistic mathematics approach. research subject will be $4^{\text {th }}$ grades students of SDN 20 Indarung Padang. 


\section{RESEARCH METHODS}

This research used classroom action research. Classroom action research is an action research that is aimed to improve the quality of learning processes (Kunandar,2012:45). The research subjects are chosen based on several considerations which are (1) principals and teachers are willing to accept learning reform with PMR approach, 2) no fractional summation has been added with PMR approach in SDN 20 Indarung Kota Padang, 3) they are students that are observed and encounter low learning outcomes in mathematics.

The subjects will be teachers teach in and $4^{\text {th }}$ grade students of SDN 20 Indarung Padang who registered in 2015/2016 academic year. There are 15 female students and 17 male students.

Data collection will use observation and test. Aspects observed through the observation guidelines are related to the lesson plan (RPP), the implementation of learning on the aspects of teachers and aspects of students. The test sheet is used to reinforce the observational data that occurs in the class, especially on the grain of mastery of learning materials by students. This research uses a qualitative and quantitative approach. Qualitative approach is used because it produces data in the form of exposure and descriptive form of written words and observed behavior of information sources and without using statistical techniques. According to Emzir (2011: 28) a qualitative approach is "an approach that uses research strategies such as narrative, phenomenological, ethnomathematics, grounded theory studies, or case studies." The application of quantitative data analysis models to student learning outcomes using the assessment formula proposed by Purwanto 2006: 102) with the following formula:

$\mathrm{P}=N P=\frac{R}{S M} \times 100 \%$

Information:

NP : the calculated or expected Percentage

$\mathrm{R}$ : the learner score

$\mathrm{SM}$ : the maximum score

Qualitative data processing guidance (Purwanto, 2006:103)

\begin{tabular}{|c|l|l|l|}
\hline Mastery level & Grade & Quality & Yudisium \\
\hline $86-100 \%$ & SB & 4 & Very good \\
\hline $76-85 \%$ & B & 3 & Good \\
\hline $60-75 \%$ & C & 2 & Enough \\
\hline $55-59 \%$ & K & 1 & Less \\
\hline$\leq 54 \%$ & KS & 0 & Very less \\
\hline
\end{tabular}

\section{RESEARCH RESULT}

\section{Cycle I}

There are two meetings in the first cycle. The activities that are observed are 1) planning, 2) implementation which includes: a) the use of context in the representation, listening, and reading (B) use of models for progressive mathematics, c) utilization of student construction results, d) interactivity, e) relevance; 3) observation; and 4) reflection. The processes will be discussed as follows:

\section{Planning}

Planning phase consists of Teachers in planning actions make preparations consisting of lesson plan (RPP), student worksheets (LKS) and data collection instruments used in the form of observation sheet RPP, teacher activity observation sheets, student activity observation sheets, affective aspects observation sheet, psychomotor aspect observation sheet and cognitive aspect evaluation question. 


\section{Implementation}

The first meetin of cycle I was held on Monday March 7, 2016 and the second meeting was held on Wednesday March 9, 2016. The learning process that was implemented is based on RME approach combine with mathematical communication indicators. The processes are (1) use of context in representation, listening, and re-reading of the subject matter. Context or realistic problems are used as the starting point of mathematics learning. Context does not have to be a real world but can be in the use of props, or other situations as long as it is meaningful and imaginable in the minds of students; (2) The use of models for progressive mathematization in discussions. The use of the model serves as a bridge from a concrete level of mathematical knowledge to formal-level mathematical knowledge; (3) Utilization of student construction result in discussion. Students have the freedom to develop problem-solving strategies so that varied strategies are expected; (4) Interactivity, the learning process of students will be shorter and meaningful when students communicate with each other their work and ideas; (5) interconnectivity which means a mathematical learning is expected to introduce and build more than one mathematical concept simultaneously.

\section{Observation}

Based on the result of observations that are done by teachers and colleagues, it $\mathrm{cn}$ be interpreted as follows:

\section{Results of first observations}

\begin{tabular}{|l|c|c|}
\hline \multicolumn{1}{|c|}{ Aspects } & value & Grade \\
\hline $\begin{array}{l}\text { Implementation of lesson } \\
\text { plan }\end{array}$ & $89.29 \%$ & SB \\
\hline Teacher activity & $75 \%$ & C \\
\hline Students activity & $77.5 \%$ & B \\
\hline Cognitive & 74.22 & C \\
\hline Affective & 64.54 & $\mathrm{C}$ \\
\hline Psychomotor & 66.54 & $\mathrm{C}$ \\
\hline
\end{tabular}

\section{Reflection}

Based on the observation in the cycle I, there are several improvements that should be designed. The improvements are: (a) doing discussion earlier and more time, (b) clarifying learning objectives so that students can grasp a fully understanding. (c) students' involvement in group discussion needs to involve (d) motivating students to participate actively in group discussion, responding and displaying the discussion result with more confidence using the language that is easy to understand by the listener .

\section{Cycle II}

The activities that are observed in cycle II are 1) planning, 2) implementation which includes: a) the use of context in the representation, listening, and reading (B) use of models for progressive mathematics, c) utilization of student construction results, d) interactivity, e) relevance; 3) observation; and 4) reflection. The processes will be discussed as follows:

\section{Planning}

Based on the results of study and observation cycle $\mathrm{I}$, researchers design new lesson plan and student's worksheet (LKS). The instruments will be the same with instruments that are used in the cycle I. 


\section{Implementation}

Implementation on the second cycle was held on Monday of March 14, 2016. In the implementation of designed lesson plan, researchers act as the as a practitioner or teacher, while teachers and colleagues as observers.

The learning process that was implemented is based on RME approach combine with mathematical communication indicators. The processes are (1) use of context in representation, listening, and re-reading of the subject matter. Context or realistic problems are used as the starting point of mathematics learning. Context does not have to be a real world but can be in the use of props, or other situations as long as it is meaningful and imaginable in the minds of students; (2) The use of models for progressive mathematization in discussions. The use of the model serves as a bridge from a concrete level of mathematical knowledge to formal-level mathematical knowledge; (3) Utilization of student construction result in discussion. Students have the freedom to develop problem-solving strategies so that varied strategies are expected; (4) Interactivity, the learning process of students will be shorter and meaningful when students communicate with each other their work and ideas; (5) interconnectivity which means a mathematical learning is expected to introduce and build more than one mathematical concept simultaneously.

\section{Observation}

Based on the result of observations that are done by teachers and colleagues, it $\mathrm{cn}$ be interpreted as follows:

\section{Results of first observations}

\begin{tabular}{|l|c|c|}
\hline \multicolumn{1}{|c|}{ Aspects } & value & Grade \\
\hline $\begin{array}{l}\text { Implementation of lesson } \\
\text { plan }\end{array}$ & $96.43 \%$ & SB \\
\hline Teacher activity & $95 \%$ & SB \\
\hline Students activity & $95 \%$ & SB \\
\hline Cognitive & 83.75 & B \\
\hline Affective & 80.47 & B \\
\hline Psychomotor & 80.47 & B \\
\hline
\end{tabular}

\section{Reflection}

It can be concluded that the research on cycle II has been implemented very well, so that student learning outcomes have increased. Student learning outcomes have reached the completeness that has been formed with minimal mastery criteria (KKM) is 75 . Thus, the increase in the result of the addition of the fractions with PMR approach has been successful.

\section{DISCUSSION}

\section{Cycle I}

The cycle I is the first time for teacher and student getting involve in realistic mathematic education approach in learning addition of fraction. students and teachers face difficulties. As the result, the implementation of the lessons have not maximal.

\section{Planning}

The planning of the teachers in the study consists of several components: (1) Standard Competence, (2) Basic Competence, (3) Indicator, (4) Learning Objectives, (5) Main Material, (6) Evaluation. Standard of competence and basic competence is taken from KTSP subjects of Mathematics for $4^{\text {th }}$ grade students in elementary school. The lesson plan is well prepared by analyzing basic 
competencies of learning materials. based on the observation sheet, it is obtained the successful of designing and implementing the designed lesson plan is $89,29 \%$ (SB).

\section{Implementation}

Learning activities with PMR approach can help students find the concept of mathematics in the fractional addition. All the characteristics of PMR has been well implemented. It's just that there are still several parts that are not wellimplemented. There are several improvements in students' activity and involvement in mathematics learning processes.

\section{Observation}

Observation of teacher aspect in cycle I obtained percentage value average $75 \%$ (C). There are still some shortcomings from the implementation of learning aspects of teachers in this cycle. While the results of observations on student aspects obtained the percentage of the average value of 77.5 (B). In the aspect of students there are also shortcomings such as students have not been actively involved in the discussion.

\section{Student learning outcomes}

Assessment of learning outcomes in cycle I that consists of assessment process and assessment results. Assessment of the affective sequence process undertaken at the time of the learning begins till the learning ends, which is considered an attitude with an average grade of 66.54 (C). Psychomotor aspect assessment obtained an average value of 66.54 (C). Assessment of results in the form of cognitive domain students do when answering questions / tests given at the end of learning with an average value of $74.22(\mathrm{C})$.

\section{Cycle II}

\section{Planning}

Learning from the mistakes that is made in cycle $\mathrm{I}$, the designed lesson plan of Cycle II have improve significantly due to the effectivity of the instrument. The percentage of effectivity of lesson plan is $96.43 \%$. This value is higher that the effectivity of lesson plan in the cycle I. It means that the lesson plan in the cycle is better than cycle I.

\section{Implementation}

The result of analyzing observation data of teacher and student activity shows that significant changing in both aspects. Teacher aspect based on observation $95 \%$ or it can be categorized as very good. Students' aspects showed a significant increased which is from $77.5 \%$ up to 95\% (very good level).

\section{Student learning outcomes}

Student learning outcomes in cycle II have an average learning outcome of 83.75 (B). It is also seen in the affective aspect to obtain an average value of 80.47 (B) and the psychomotor aspect observation results obtained an average value of 80.47 (B). The number of students who completed 27 people out of 32 people

Judging from student learning outcomes starting from cycle I and cycle II continue to increase. This suggests that the fractional addition learning with realistic mathematics education approach has succeeded in improving $4^{\text {th }}$ grade student learning outcomes of SDN 20 Indarung Kota Padang. 


\section{CONCLUSION AND SUGGESTION}

Based on data of research result and discussion about how to teach addition of fraction with different denomination by using Realistic mathematics education approach, it can be concluded that 1) the successful of planning lesson plan by using realistic mathematics education approach has resulted in the improvement of students learning outcomes, teacher activity, and students' activity. the successful of planning a lesson plan has improve continuously from cycle I which is $89.29 \%$ to cycle II which is $96.43 \%$; 2) teachers's activity has improve from $75 \%$ to $95 \%$ and students' activities also showed significant improvement from $77.5 \%$ in cycle I becomes $95 \%$ in cycle II; 3 ) it is also influenced students learning outcome in cognitive, affective and psychomotor domain. the average of students learning outcomes of these three domains are increased similarly from cicle I to cycle II. The cognitive aspects increase from 74,22 to 83,75 . The affective domain of cycle I average of 66.54 increase to 80.47. The average psychomotor domain increase from 6.54 (C) to 80.47 .

Based on the above conclusions, the researcher proposed several suggestions: (1) For the researcher to conduct more indepth study on mathematics subjects especially on the material of the addition of different denominations using realistic mathematics education approach; (2) Realistic mathematics approach can be considered as an approach that can be used in teaching addition of fraction with different denomination concepts. (3) readers should be able to add insight about the implementation of RME and can be used as an alternative approach to learning and must be tailored to the material being taught.

\section{REFERENCES}

BNSP. 2006. Kurikulum Tingkat Satuan Pebdidikan. Jakarta: Depniknas..

Depdiknas. 2006. Kurikulum Tingkat Satuan Pendidikan Jenjang Pendidikan Dasar. Jakarta: Depdiknas

Emzir. 2011. Metodologi Penelitian Pendidikan Kuantitatif Dan Kualitatif. Jakarta: Rajawali Pers

Fauzan, Ahmad. 2002. Applying Realistic Matehematic Education(RME) in Teaching Geometry in Indonesin Primari Schools. Disertasi.

Kunandar. 2012. Langkah Mudah Penelitian Tindakan Kelas. Jakarta: PT Rajawali Press

Zainul, Asmawi \& Mulyana, Agus. 2007. Materi Pokok Tes dan Asesmen di $S D$. Jakarta: Universitas Terbuka

Purwanto, Ngalim. 2004. Prinsip-Prinsip Dan Teknik Evaluasi Pengajaran. Bandung: PT Remaja Rosdakarya 